\title{
DIREITO OU DISCURSO? REFLEXÕES SOBRE O "SONHO" DA CASA PRÓPRIA NO BRASIL E EM FORTALEZA-CE (1930-1974)
}

\section{RIGHT OR SPEECH? ANALYSIS ABOUT THE "DREAM" OF HOME- OWNERSHIP IN BRAZIL AND IN FORTALEZA (1930-1974)}

Angerlania da Costa Barros ${ }^{1}$

RESUMO: Este artigo aborda a construção ideológica e política do ideal ou "sonho" da casa própria no Brasil e de como isto influenciou e tornou-se um discurso do governo municipal de Fortaleza, ao realizar a remoção da favela Arraial Moura Brasil durante a década de 1970. Pretendemos entender como os poderes (federal, estadual e municipal) políticos criaram um discurso providencialista em torno de um dos direitos humanos, a moradia, e passaram a utilizá-lo enquanto um instrumento de convencimento da populaçáo pobre, a fim de que ela acreditasse que as políticas habitacionais preocupavam-se em garantir este direito a todos. Para tanto,utilizamos publicaçóes dos jornais $O$ Povo e Correio do Ceará, bem como relatórios municipais de Fortaleza acerca da retirada do Arraial Moura Brasil, contrapondo estes discursos oficiais com as falas de alguns moradores chamados de "removidos".

PALAVRAS-CHAVE: Moradia. Política habitacional. Exclusão.

ABSTRACT: This article seeks to reflect on the ideological and political construction of the ideal or "dream" of own house in Brazil and how it influenced and became a discourse of the municipal government of Fortaleza, when carrying out the removal of the "favela" Arraial Moura Brazil during the 70's. We intend to understand how the government (federal, state and municipal) powers created a providential discourse around one of the human rights, housing, and began to use it as an instrument of convincing the less well-off population, to That they believed that housing policies were concerned with securing this right for all. In this context, we used old publications from local newspaper (O Povo and Correio do Ceará) and also local documentations from Fortaleza about the removal of the community Arraial Moura Brasil. In opposite this documentation we used the relat comes from local cityzens called "removidos".

KEY-WORDS: Dwelling; Housing state policy; Exclusion.

\section{O INSTRUMENTO E A RECOMPENSA: A CASA PRÓPRIA COMO MUDANÇA}

Com a chegada de Getúlio Vargas à presidência do país, em 1930, a problemática sobre a moradia assumiu novos contornos, pois, até então, não existiram programas nacionais de construção de casas populares. Para o arquiteto e urbanista Nabil Bonduki, no

Mestranda em História pela Universidade Estadual do Ceará/UECE. e-mail: angel_htaa@hotmail.com 
Governo Vargas, a habitação foi encarada como um [...] elemento na formação ideológica, politica e moral do trabalhador e, portanto, decisiva na criação do "homem novo" e do trabalhador-padrão que o regime queria forjar, como sua principal base de sustentação política [...] (BONDUKI, 1998, p. 73).

De acordo com as ideias de Alfredo Bosi, em Dialética da Colonização, Getúlio Vargas acreditava no [...] principio de um Estado suficientemente forte para mediar tanto os conflitos entre os setores das classes dominantes como as tensóes entre estas e os trabalhadores [...] (BOSI, 1992, 288).Dessa forma, Vargas atuava como coordenador e disciplinador dos interesses coletivos em todos os setores sociais, econômicos e políticos.Para nós, isto explica o porquê de se planejarem medidas mais organizadas para resolver a questáo habitacional, principalmente, a habitação popular, ou melhor, a habitação do trabalhador.

A provisão de casas aos pobres foi apenas um aspecto de sua atuação. Possibilitar uma moradia ao trabalhador envolvia, simultaneamente, agraciar o interesse pessoal do operário e aumentar o controle de seus patróes e do próprio Estado sobre eles, na medida em que os trabalhadores "andariam na linha" por medo de perder o emprego e a casa. Para o sociólogo Sergio de Azevedo (1988), as medidas habitacionais no Governo Vargas não primavam pelo beneficiamento das populaçóes pobres, mas sim pela obtenção de apoio delas ao novo presidente. Em outras palavras, o principal objetivo da primeira intervenção do Estado no problema de habitaçáo no país era conseguir a adesão de trabalhadores ao novo regime:

A partir dessa época (1930), as políticas públicas voltadas para os setores populares visam também aumentar a margem de legitimidade do Estado. As primeiras intervençôes públicas na área de habitação popular inserem-se nesse contexto e têm fundamentalmente como objetivo mostrar às populaçóes urbanas de baixa renda a preocupação do governo com seus problemas (AZEVEDO, 1988, 107).

Uma das formas de alcançá-los foi através de um ideal (criado pelo Governo), destinado aos trabalhadores urbanos assalariados, em torno das vantagens de se ter uma casa própria. O ideal serviu como uma forma de Vargas se aproximar mais de seu principal público-alvo - o trabalhador. Para Bonduki $(1988,86)$, esse ideal da casa própria e as políticas habitacionais eram destinados aos trabalhadores urbanos assalariados, porque era sobre eles que o regime se apoiava. Em resumo, os operários não morariam mais em um lugar alugado e ainda se tornariam proprietários de suas casas, logo, eles veriam o quanto "o pai dos pobres" preocupava-se com eles e com a ascensão social deles. Segundo Aragão (2010, p. 17), [...] a habitação foi peça importante no discurso conservador que pregava a importância do trabalhador em tornar-se proprietário de sua moradia e da estabilidade social que a politica habitacional poderia promover [...]. A autora comenta sobre o uso desses programas também como forma de evitar contestaçóes dos trabalhadores contra o Estado.

Entretanto, nosso foco não é analisar o ideal em si ou os seus objetivos, mas compreender o que representava para os brasileiros ter uma moradia própria. Segundo Dilvo Peruzzo (1984), foi a partir desse ideal que a casa própria passou a ser um objeto de desejo dos trabalhadores. Pois, como comenta Bonduki (1998), a casa não representava apenas 
um local de segurança familiar, mas promovia tranquilidade em relação à instabilidade do morar de aluguel e, sobretudo, conferia status, uma ascensão social:

\begin{abstract}
A casa representava a segurança de um abrigo permanente; a garantia de morar, a médio prazo, praticamente a custo zero; a possibilidade de conferir uma renda extra com a sublocação de cômodos no lote; a perspectiva concreta de entesourar, acumular - não de enriquecer, mas de dispor de um bem de valor muito mais alto em relação ao preço do trabalho assalariado. Ela permitia, ainda, amoldá-la aos desejos da família [...] (BONDUKI, 1988, p. 309).
\end{abstract}

Se possuir uma moradia já era almejado pelas famílias do país, imaginar-se com este sonho realizado (devido à política varguista) fez as esperanças aumentarem. Embora os Institutos de Aposentadoria e Pensão (IAP) ${ }^{2}$ não tivessem efetivado uma política habitacional, o que parecia distante (obter uma casa própria) aos trabalhadores, estava prestes a se concretizar. Mas o ideal também ocasionou uma ressignificação do valor simbólico da habitação. A casa própria, desde a década de 50, deixou de ser apenas um abrigo e passou a ser, como aponta Maricato (1987), uma mercadoria, além de que possuí-la transformava o simples trabalhador em um proprietário.

Assim, consequentemente, a compra da casa própria subordinou ainda mais o empregado ao patrão, pois, perder o emprego também significava perder a casa.Todavia, a moradia subordinava, principalmente, os trabalhadores ao Estado. A intenção deste, quando elaborou o ideal, foi justamente essa. Na prática, o Estado se apropriou de um bem extremamente necessário à vida humana (o qual, desde 1948, foi instituído como um dos direitos universais do homem ${ }^{3}$ ) e o transformou em um objeto de troca, de compensação e, sobretudo, de controle da população pobre e trabalhadora.

Quando a política habitacional brasileira, implantada em 1964, no Regime Militar, continuou a utilizar-se desse ideal da casa própria, os objetivos eram quase os mesmos presentes na Era Vargas: além de legitimar o regime, ele mantinha os trabalhadores focados (controlados) em comprar uma casa. Esta era o instrumento da política, ou melhor, o mecanismo utilizado pelo Estado para atrair a população ao novo governo. A criação de uma política habitacional, a nosso ver, tinha o intuito de fazer a população mais pobre acreditar que "ganhar" uma habitação era fruto de um auxílio providencial do governo e não a garantia de seu direito: [...] se ela fosse concebida como direito, deveria beneficiar a todos e da mesma maneira [...] (CARVALHO, 2016, p. 119). Porém, de acordo com o Carvalho (2016), o poder federal só favorecia aqueles que pertenciam aos sindicatos.

2 Decreto-Lei no 22.872, de 29 de junho de 1933/ Art. 10: "Fica criado, com a qualidade de pessoa jurídica e sede na Capital da Republica, o Instituto de Aposentadoria e Pensóes dos Marítimos, subordinado ao Ministério do Trabalho, Indústria e Comércio e destinado a conceder ao pessoal da marinha mercante nacional e classes anexas os benefícios de aposentadoria e pensóes na forma estatuída neste decreto”. Disponível em: http://legis.senado. gov.br/legislacao/ListaNormas.action? numero=22872\&tipo norma=DEC\&data=19330629\&link=s. Acesso em ago. de 2016.

3 Declaração Universal dos Direitos Humanos. Paris, 10 de Dezembro de 1948. Artigo XXV. Parágrafo 1: “Todo ser humano tem direito a um padrão de vida capaz de assegurar-lhe, e a sua família, saúde e bem-estar, inclusive alimentação, vestuário, habitação, cuidados médicos e os serviços sociais indispensáveis, e direito à segurança em caso de desemprego, doença, invalidez, viuvez, velhice ou outros casos deperda dos meios de subsistência em circunstâncias fora de seu controle.” Disponível em: http://www.onu.org.br/img/2014/09/DUDH.pdf. Acesso em set. de 2014. 
O programa habitacional também nascia como uma maneira de apresentar soluçôes frente à conjuntura econômica, política e social pela qual o país passava no início da Ditadura Militar. Existia a necessidade de desenvolver a economia brasileira, que estava bastante inflacionária e legitimar o novo governo com o apoio das massas. Com a Política, tentou-se conseguir ambos, de uma vez só. O programa veio aquecer o setor de construção civil (ramo que mais empregava mão de obra de baixa qualificação) construindo, justamente, o principal objeto de desejo desses empregados: moradias. Em suma, a casa era o instrumento. Ela ajudava no crescimento da economia, na geraçáo de empregos e, sobretudo, garantia ao Estado o poder sobre a população pobre.

Esse poder ou controle sobre as massas surge quando os militares, nesse contexto, fazem da casa-instrumento a casa-recompensa. A moradia passou a ser um objeto de troca, ou melhor, quando havia alguma pretensão política do Estado que esbarrasse no aspecto social, como ocorreu no caso do Arraial Moura Brasil, ${ }^{4}$ a casa era a barganha. A moradia, ao mesmo tempo, era o instrumento do Estado e a recompensa da populaçáo. Para esta, ela também era sinônimo de mudança. Pois, como afirma Maricato $(1987,26),[\ldots]$ a casa própria, mesmo quando se trata de um simples embriāo de alvenaria sem revestimento, é motivo de grande segurança e sensação de progresso pessoal para o trabalhador [...].

Em Fortaleza, isso aconteceu do mesmo modo. Percebemos que a casa própria também foi usada como uma forma de compensar os pobres dos eventuais projetos urbanos da cidade de Fortaleza, na década de 1970. A partir da análise dos jornais ( $O$ Povo e Correio do Ceará) e do exame das entrevistas de alguns removidos - palavra usada pela Prefeitura de Fortaleza para designar as pessoas que foram excluídas, retiradas de um local para outro - do Arraial Moura Brasil inferimos que a garantia de se obter uma casa própria foi um dos maiores pretextos usados pela Prefeitura de Fortaleza para convencer o povo a sair passivamente da área prometida às melhorias urbanas.

Observando a política de desfavelamento ${ }^{5}$ da capital cearense, notamos que os administradores do município se utilizaram desse instrumento (habitação)de forma simbólica. Para melhor explicar, a Prefeitura de Fortaleza usava a promessa da casa própria, mas garantia apenas lotes - um terreno que serviria à construção da moradia. Isto é, os removidos compravam o espaço destinado à realização do sonho (a casa) e não o sonho propriamente dito. Entretanto, sendo simbólica ou não, a casa era a recompensa, o prêmio. Mesmo que ser removido fosse negativo, ela compensava o infortúnio, como podemos perceber na fala de Dona Raimunda, uma das removidas do Arraial:

Antes de vim, eu visitei (o lote) menina, aqui era só o matagal, mas eu vim, a casa ia ser minha, né? Eu vim, não ia pagar mais aluguel. Eu sabia desses conjuntos Alvorada, Palmeiras, mas eu

Chamamos Arraial Moura Brasil todas as favelas antes localizadas próximo ao litoral fortalezense, entre a Rua General Sampaio e a Rua Filomeno Gomes, na altura da Escola de Aprendizes Marinheiros. Entre elas, citamos: o Moura Brasil, a Braga Torres, o Soares Moreno e o Oitão Preto. A favela de Cinza também está incluída, pois, apesar de não fazer parte do Arraial, ela compartilhou o mesmo processo de remoção e muitos de seus exmoradores foram deslocados para o Conjunto Marechal Rondon.

O termo era utilizado pelo governo municipal de Fortaleza e se referia à prática de extinguir as áreas de moradias da população mais pobre, vulgarmente chamadas de favelas. 
preferi vim pro Rondon.Eu queria vim, ter minha casa, né? Foi uma luta, mas agora eu tenho minha casa. Eu vim porque eu ia ganhar minha casa (SILVA, 2014). ${ }^{6}$

As entrevistas com alguns dos antigos moradores do Arraial e da favela José Bastos apresentam-se como contraponto em relação às fontes impressas, ou melhor, elas serviráo para analisarmos a prática de eliminação de zonas pobres segundo os que a vivenciaram de fato, buscando detalhes náo contidos (amenizados ou omitidos) nos jornais e nos relatórios. O confronto entre as falas e as outras duas tipologias de fontes é uma tentativa [...] de ir além daquilo que é dito, ver além daquilo que é mostrado [...] (PESAVENTO, 2014, p. 64), buscando apreender nas entrevistas o quanto a exclusão socioespacial estava imbricada na sociedade fortalezense, de que maneira eles viam e reagiram à expulsáo e qual tratamento eles receberam durante o processo. Tarefa que, segundo Pesavento, não é fácil, pois "[...] aquele que lembra não é mais o que viveu. No seu relato já há reflexão, julgamento, ressignificação do fato rememorado [...]” (PESAVENTO, 2014, p. 95).

Os entrevistados, ao serem perguntados sobre qual foi a maior vantagem de terem ido ao Conjunto Rondon, são unânimes na resposta: ter a casa própria. E quando interrogados se se sentiram excluídos, quando foram retirados do Arraial, a resposta é parecida: Não, porque eu ia ganhar minha casa (SILVA, 2014). Por mais que gostassem e sentissem saudade da área em que moravam ou que não quisessem ir ao conjunto, a recompensa valia à pena: A gente sentia saudade (do Arraial), mas a casa não era minha, agora eu teria minha casa mesmo, né? (SILVA, 2014). Por essa fala, também apreendemos que um dos fatores facilitadores da não contestação da remoção por parte dos favelados era a saída do aluguel.

Sair do aluguel também significava uma melhoria de vida. Segundo a fala de Francisco Matias, apesar do aluguel da casa em que morava no Arraial náo aumentar de valor, ${ }^{7}$ sua família aceitou mudar-se para o conjunto, a fim de náo precisar mais ser inquilino: Era melhor pagar por uma coisa (casa) nossa (SOUZA, 2014). Todavia, um dos maiores fatores da remoção ter sido bem-sucedida (sem muitas contestaçôes e/ou resistências) e até aceita por eles foi, além da promessa desse presente (moradia), o apoio de lideranças/ representantes locais à Fundação do Serviço Social de Fortaleza (FSSF), um dos órgãos responsáveis pelo "desfavelamento", para o convencimento da população:

As lideranças locais foram conquistadas na sua quase totalidade. Experientes em negociar com os agentes externos, que sempre atuaram nas favelas (funcionários de diversos organismos da administração, políticos, assistentes sociais, etc.), conhecendo sua margem de negociação no jogo e conscientes também das limitaçóes de suas bases de apoio, os "representantes da favela” entraram na nova jogada. Às lideranças conquistadas cabia o papel de trabalhar junto à população, visando a ganhar as vozes divergentes (VALLADARES, 1980, p. 51).

$6 \quad$ Depoimento de Raimunda Leopoldina e Silva (77 anos), moradora do Conjunto Marechal Rondon. Removida do Arraial Moura Brasil em 1973.Entrevista feita em 09 de agosto de 2014.

7 Informaçóes de Francisco Matias de Souza (74 anos), morador atualmente do Parque Guadalajara em Jurema, próximo ao Conjunto Rondon. Foi removido do Arraial Moura Brasil em 1973. Segundo ele, o dono do imóvel em que morava não aumentava o valor de seu aluguel (entre 1964-1970), mas, muitas vezes, sua pouca renda não permitia o pagamento do mesmo. Entrevista feita em 06 de setembro de 2014. 
Desconhecemos algum líder que tenha colaborado com a política de desfavelamento no Arraial Moura Brasil, mas, no contexto do Conjunto Marechal Rondon, apontamos a Dona Edith ${ }^{8}$. Pelo seu depoimento, ela sempre apoiou o programa de desfavelização da Prefeitura e atuou junto à FSSF e ao Centro Social Urbano (CSU)como porta-voz da populaçáo que, paulatinamente, chegava ao Conjunto Rondon. Quando perguntada sobre o porquê de ela consentir com o tal plano, sua resposta reproduz o discurso do programa e dos jornais: "Era muito bom o plano da Prefeitura de tirar as pessoas dali, ali náo tinha vida, era uma favela. A gente tava era bem, vindo pra cá.” (DIAS, 2014).

Os discursos da FSSF, da política de desfavelamento, e as constantes propagandas nos jornais sobre as mudanças positivas que a população teria se saísse do Arraial, fizeram muitos dos excluídos julgarem o programa justamente assim, como um benefício aos pobres. Portanto, a Dona Edith apoiava a remoção por entender a retirada dos moradores do Arraial como uma açáo benéfica àquela população pobre e favelada e não como uma prática excludente. Porém, a sua opinião difere dos outros dois entrevistados.

Para Seu Francisco e Dona Raimunda, sair de seu local de moradia só teve de positivo a obtençáo da casa própria. Se a Prefeitura tivesse urbanizado a favela ou construído casas para vender no próprio Arraial, eles dizem que, certamente, teriam ficado lá. Também devemos considerar que a Dona Edith não residia no Arraial, não veio ao conjunto na condição de removida e tinha (tem) uma melhor posição financeira que outros. Assim, para a Dona Edith, vir ao conjunto e ter uma casa própria náo foi um símbolo de mudança ou de recompensa, visto que ela já possuía uma, antes de chegar ao Rondon. Na verdade, segundo ela, a maior vantagem de mudar-se para o Marechal Rondon foi conseguir ter tranquilidade de poder cuidar de si e dos seus filhos:

\footnotetext{
Eu saí de lá é porque lá eu não tinha vida, não tinha pra onde, né? Não tinha uma área de lazer, não tinha nada. Me "avexei" (apressei) mesmo e até achei bom sair da beira da praia, foi a minha saúde e a saúde dos meus filhos, que lá tudo cansavam, qualquer gripezinha, tavam cansados, eles não estavam se dando com a maresia que já tava batendo no fundo das casas [...] Só aqui eu virei cidadã.Porque lá era beira de praia, uma ruazinha muito estreita, sem calçamento, sem nada, do lado do Moura Brasil que era uma grande favela, né? E ali não tinha vida, ninguém tinha vida (DIAS, 2014).
}

Pela fala acima, percebemos que, para a Dona Edith, a recompensa foi a mudança do espaço. Seu desejo, quando resolveu por conta própria comprar um lote da FSSF, foi sair (e tirar seus filhos) de perto daquela grande favela ou, como diziam os jornais e os planos urbanísticos, daquela desordem. Na visão de Dona Edith, os favelados ao mudar-se para o conjunto teriam uma vida melhor. De fato, com exatamente 44 anos passados, são perceptíveis as melhorias urbanas, mas quando da chegada ao Rondon, a situação dos removidos, em alguns aspectos, parecia praticamente a mesma.

\footnotetext{
$8 \quad$ Uma de nossas entrevistadas, Maria Edith Ferreira Dias (85 anos), era moradora da Rua Gomes Parente, bem próximo à favela do Braga Torres, no Arraial Moura Brasil. Ela aponta que não foi removida ao Conjunto Rondon, pois veio por conta própria. Diz também que chegou ao conjunto um pouco antes que os removidos do Arraial, atuando, desde sua chegada, como líder comunitária e catequética do local. Muitos moradores removidos e antigos do Conjunto Mal. Rondon a tem como uma referência. Entrevista feita em 09 de agosto de 2014.
} 
Existia ainda uma estratégia dos administradores municipais de disfarçar a exclusão socioespacial destes moradores: eles apresentavam três opçóes de escolha aos removidos, a fim de aparentar que a ida deles aos conjuntos náo era uma imposição: Não foi forçado não, tinha para o Pirambu, tinha para o Palmeiras, tinha para outros canto, né? E eu escolhi aqui (Rondon) (DIAS, 2014). Isso também implica em dizer que não importava muito para o governo municipal saber o destino dos ocupantes do Arraial, o que eles queriam e exigiam, de fato, era o esvaziamento das áreas prometidas ao (re)ordenamento urbano. A ordem era retirar, esta era missão dada à FSSF e aos outros órgáos envolvidos. O Programa Integrado de desfavelamento pretendia extinguir trinta e dois aglomerados precários da capital até o ano de 1980 e conferia mais essa característica de solucionar os problemas do espaço citadino que o objetivo de prestar assistência aos seus habitantes pobres.

Este programa surgiu para esconder a miséria, a desordem e a feiura dos olhos da elite e trazer beleza à paisagem fortalezense para agradar seus visitantes. Outro fator dessa retirada de favelados da área central e litorânea de Fortaleza foi dividir, oficialmente, o espaço urbano entre as classes. Nos melhores locais, isto é, nos terrenos valorizados pela especulação imobiliária, por possuírem infraestrutura e serviços urbanos, ficaram os que podiam pagar. No caso do Arraial, ficou a avenida, afinal o que seria melhor para a capital: manter uma grande área indesejada pela elite e pelos governantes ou construir uma artéria que melhoraria o sistema viário, traria uma nova fisionomia para a cidade e, sobretudo, apagaria os vestígios de pobreza ali existentes?

Conforme nossas leituras, o conjunto habitacional seria o local do pobre nas cidades, pensado para, além de receber e abrigar as populaçóes de menor poder aquisitivo, estabelecer uma ordem socioespacial. Construir conjuntos destinados às pessoas economicamente desfavorecidas na periferia de Fortaleza e/ou em outras capitais, que se pretendiam modernas, à época, era uma tentativa não só de eliminar as chamadas favelas e controlar o uso do espaço urbano, mas também de esconder a pobreza dos "olhos" ricos e turísticos.

Se os agentes destas políticas afirmavam que resolveriam o déficit habitacional pelo viés social, acabariam com o problema das "favelas" e facilitariam a compra de moradias pela população de baixa renda, eles só cumpriram a última alternativa e ainda de forma relativa. Além disto, a concessão de casas (ou lotes) aos cidadãos pobres era apresentada como um presente dos governantes e náo o cumprimento de um dos deveres do Estado.

A casa, o fim do aluguel e a saída daquela desordem eram os pretextos mais utilizados pelo Programa de desfavelamento de Fortaleza, a fim de convencer os moradores do Arraial a não contestar a remoção e se sentirem premiados pela política. De fato, os removidos confirmam que o maior benefício com a ida ao conjunto foi a moradia própria. Mas, existiam outras vantagens no Conjunto Rondon, além da moradia? E o que representou para eles a construçáo da Avenida Leste-Oeste? Eles se sentiram integrados aos melhoramentos urbanos que ocorriam na cidade naquele período? Analisaremos essas questóes a partir de agora. 


\title{
O REMOVIDO E A CIDADE: HOUVE INTEGRAÇÃO?
}

\begin{abstract}
Não é preciso ser curioso e muito menos ser repórter. Quem passa pela Avenida Presidente Castelo Branco, nas imediaçôes da igrejinha de Santa Teresinha, ao olhar para favela que a circunda, enxerga logo uma choça improvisada, situada em um barranco, verdadeiro contraste às margens de uma suntuosa artéria que a todos encanta e são muitos os que vão passear, por ali, a fim de "curtirem" a beleza e paisagem, proporcionada pelos verdes mares. Se de um lado o transeunte tem oportunidade de observar uma linda paisagem, sentindo também que o progresso chegou a Fortaleza, do outro lado se depara com um quadro bem diferente, que não é um atestado de progresso e sim de miséria, pessoas de uma pobreza franciscana vivendo em casas de taipa, verdadeiros tugúrios, que um vento mais forte é capaz de desfazê-las e levar seus tetos pelos ares [...] (Correio do Ceará, 24/10/1974, p. 8).
\end{abstract}

A notícia acima, advinda do jornal Correio do Cearấ revela muito sobre o que a avenida, recém-inaugurada, ${ }^{10}$ representava para a cidade, ou melhor, para uma parte dela. A artéria era apresentada por este periódico como um símbolo de progresso urbano, além da garantia de apagar os vestígios de miséria e desordem do centro da capital. Levando-se em consideração o contexto ditatorial e a forte censura presente nos meios de comunicação, podemos inferir que as propagandas positivas em torno da necessidade de se construir vias eram consequência do controle midiático e do uso destes veículos como legitimadores das medidas tomadas pelos políticos.

Pela mesma publicação, notamos que a permanência de casebres próximos à avenida ainda era um incômodo, ou pior, era mais indesejada que antes, porque contrastava com a bela avenida. Mas, será que a construção desta não incomodava os antigos moradores também? Ou eles se sentiam integrados e/ou beneficiados por ela? Durante os dois anos de remoção da população do Arraial para o Conjunto Rondon e a construção da via, entre 1972 e 1974, os políticos fizeram muitas promessas, das quais a principal, a nosso ver, foi a de integração urbana dos removidos. Essa, gradativamente, aconteceria, quando o Programa Integrado de desfavelamento:

Favorecesse às populaçôes removidas de núcleos erradicados, condiçôes de moradias salubres em outras áreas da cidade. Áreas essas que se adequem às suas condiçóes socioeconômicas, principalmente, no que se refere a capacidade de aquisiçấo dos terrenos e condiga com o interesse de crescimento de Fortaleza [...] (FORTALEZA, 1973)

Analisando esse objetivo dito "integrador", percebemos que, na prática, ele não promove integraçáo, pelo contrário, exclui. Dar casa a quem não tem casa ou, como no caso aqui tratado, tinha apenas um barraco, trata-se de uma medida social e assistencialista. Mas, quando essa moradia é dada para satisfazer interesses urbanísticos e econômicos,

O jornal, fundado em 2 de março de 1915, traz interesse pelo noticiário da conflagração mundial, bem como pelas ocorrências da política deveras agitada de então, tornou possível, enfim, a existência no Ceará, do verdadeiro jornalismo, de cunho informativo, preservando a linha noticiosa do "Diário do Estado", devida a Álvaro da Cunha Mendes, fundador de ambos (NOBRE, 2006). Seu acervo encontra-se impresso no Instituto Histórico do Ceará, mas de maneira entrecortada, com poucos anos completos e na Biblioteca Pública Governador Menezes Pimentel (microfilmes).

10 A Avenida Leste-Oeste foi inaugurada em cinco de outubro de 1974, com um grande festejo às margens da mesma e com a presença de políticos locais e de alguns representantes do Estado, como o Ministro da Justiça, à época, Armando Ribeiro Falcão (CORREIO DO CEARÂ, 05/10/1974, p. 8). 
a medida passa a ser compensatória, excludente, nunca integradora. Deram casas, ou melhor, terrenos, aos habitantes do Arraial, mas deram em lugares longínquos, distantes do que se pretendia modernizar.

Há mais segregação que integração, quando uma população já marginalizada, como os ex-moradores do Arraial Moura Brasil, é transferida a outros locais bem afastados dos espaços valorizados e equipados da cidade. A segregação torna-se pior, quando tal lugar se adequa ao nível socioeconômico dos ocupantes. Pois, promove-se, de fato, uma divisão do espaço urbano entre os ricos e os pobres. Não há como integrar no ato de retirar. Por mais que o plano tenha proporcionado aos removidos certa melhoria de vida, facilitando-lhes a tão sonhada casa própria, isso pode ser considerado uma integração se, na verdade, a intenção era afastá-los dos espaços valorizados da cidade?

Como integrar urbanamente moradores que nem eram considerados como pertencentes à capital cearense? Como esperar uma política de integração se os políticos nos culpavam pela desordem ou "desarmonia" do espaço urbano? Uma vez que, muito antes da implantação do Programa de desfavelamento, o Estado, através de levantamentos socioeconômicos, concluía que: [...] a população das favelas de Fortaleza é originária, na sua maioria, de lugares que náo a própria capital [...] (CEARÁ, 1967, p. 41) e que esses migrantes, quer sejam recentes ou remotos, [...] retardavam as reformas urbanas e traziam prejuizos à comunidade fortalezense [...] (CEARÁ, 1967, p. 13).

Essa visão não era exclusividade dessa época. Neves, ao falar da intensa migração de retirantes da seca à capital, no início do século XX, mostra-nos que as autoridades também relegavam aos migrantes fugidos das secas a responsabilidade/culpa pela quebra de controle e disciplinarização do espaço urbano da cidade (NEVES, 2000). Tanto que criaram os Campos de Concentração - termo utilizado pela Diretoria de Saúde Pública do Estado do Ceará, segundo consta em um documento de 03 de junho de 1932 do acervo histórico do Arquivo Público do mesmo estado - como uma forma de afastar/isolar os "invasores" da população urbana.Fazendo um paralelo com o nosso objeto, parece-nos que os conjuntos habitacionais, assim como, os Campos de Concentração foram tentativas de intervir na desordem espacial e, também, de segregar as populaçôes economicamente desfavorecidas.

A diferença entre eles se dá na maneira em que os segregados de cada os encarava. Pois, enquanto os moradores dos conjuntos se sentiam beneficiados com as políticas habitacionais, os retirantes, segundo a historiadora Kênia Rios, viam o "[...] curral (Campos de Concentração) como mais um caso que explicitava a forma cruel pela qual o Governo costumava, e ainda costuma, assistir os despossuídos" (RIOS, 2001, 68). Dessa maneira, Fortaleza não integrou as pessoas removidas, ela as afastou. E dizemos mais, a mesma imagem de atraso citadino que se tinha dos retirantes no começo do século passado, também se perpetuou aos habitantes do Arraial Moura Brasil na década de 70. Percebemos isso, quando os jornais afirmam que as características de miséria encontradas no Arraial já eram esperadas/imaginadas:

A cidade crescera por todos os lados, mas não ousara descer as ladeiras da Barão do Rio Branco, Senador Pompeu e General Sampaio, como que atemorizada pelo espetáculo de miséria que lá embaixo deveria encontrar. Agora, resolveu descer (devido às demoliçóes dos casebres 
para a construção da Avenida Leste-Oeste), e o espetáculo, salvo a inexistente agressividade presumida, era mesmo o que se imaginava (O Povo ${ }^{11}$, 17/02/1973, 1).

A imprensa teve um papel importante na propagação da imagem do Arraial, apresentando-o como um local de extrema miséria e enfermidades, a fim de legitimar o desfavelamento. Mas os jornais também expressam de que forma essa favela era idealizada pela elite fortalezense e, principalmente, pelos administradores da capital: O que apareceu aos olhos de todos não foi uma sociedade de marginais perigosos, como se supunha, mas uma estranha coleção de seres humanos carcomidos pelas doenças mais diversas, um autêntico "pátio de milagres", com aleijados, cegos, chagados e retardados (O Povo, 17/02/1973, 1).

Essas imagens, não exclusivas da favela do Arraial Moura Brasil, fizeram os políticos fortalecerem ainda mais o objetivo de afastar esses problemas das áreas centrais de Fortaleza. Assim, ao longo da década de 70, o município trocou muitas favelas por avenidas e/ou grandes obras e transformou vários favelados em removidos. A cidade (física) era (re)ordenada, melhorada e embelezada na sua parte central, ao mesmo tempo que deslocava os seus antigos moradores às periferias.

Como integrar os removidos e a cidade? Se esta, ao transformá-los em removidos, já lhes tira o direito de escolher habitar onde quiserem e de usufruir de todos os benefícios urbanos existentes no Centro de Fortaleza. Talvez, para os políticos, integrá-los fosse apenas presenteá-los com uma "habitação" própria, ou melhor, com um terreno onde eles seriam proprietários de suas casas. Interessante é perceber que os ex-moradores do Arraial ficaram convencidos disso, de que estavam sendo integrados: Só aqui eu virei cidadã, porque lá eu não tinha vida (DIAS, 2014).

Entretanto, quando perguntados sobre o que a Avenida Leste-Oeste representava para eles, naquele período, e se ela lhes trouxe algum benefício, suas respostas são diferentes e até críticas, de certa forma. Para Francisco Matias, a [...] avenida foi feita pros rico, tudo que fizeram lá não foi pra nós (removidos) não (SOUZA, 2014).

Podemos perceber também, pelas falas dos entrevistados e pelas notícias dos jornais, que a via não era de todo elogios, pois, a sua construção lenta e a sua inauguraçáo, mesmo estando incompleta, receberam muitas críticas. Eu via aquela avenida grandona, bonita, ela foi importante, mas não terminaram ela não, tinha só uma parte pronta (SILVA, 2014). O anúncio da realização dessa obra foi em 1971, o início da construção estava previsto para outubro de 72, mas só começou em fevereiro de 1973 e a sua inauguração, prevista para março de 1974, só ocorreu em outubro. Segundo os ex-moradores, depois de oficialmente inaugurada, ainda existiam em suas margens alguns casebres, muitos buracos e vários acabamentos a serem feitos.

$11 \quad$ Fundado em 07 de janeiro de 1928 pelo cearense Paulo Sarasate e por Demócrito Rocha, baiano que adotou o Ceará, tendo aqui se radicado e constituído família, o jornal é atualmente o órgáo de imprensa mais antigo ainda em circulação no estado do Ceará. (ALVES, 2010). Seu acervo encontra-se na hemeroteca (microfilmes) da Biblioteca Pública Governador Menezes Pimentel (Espaço Estação, na Praça da Estação com Rua 24 de Maio), bem como no Instituto Histórico de Ceará, localizado na Rua Barão do Rio Branco (próximo à Avenida Duque de Caxias). Algumas notícias estão disponíveis apenas na sede do próprio Jornal, na Av. Aguanambi, 282. 
Mas, voltando ao nosso questionamento, se a proposta do plano de desfavelamento era integrar ou pelo menos melhorar as condiçóes de habitação e o modo de vida dos removidos, foi a casa própria a única opção para isto? Segundo os entrevistados, não. Para eles, um dos mais vantajosos benefícios recebidos na chegada ao conjunto foi a ajuda financeira da Christian Children Fund (CCF) ou Fundo Cristão para Crianças: Para mim,o maior benefício com a vinda ao Conjunto foi ter o dinheiro da CCF (SILVA, 2014). O órgão e a ajuda não eram ligados ao governo, pois a CCF é uma organização não governamental (ONG), que atua, desde a década de 70, na realizaçáo de trabalhos assistencialistas em comunidades carentes. Atualmente, o órgão não dá mais essa quantia mensal, o auxílio se dá apenas duas vezes por ano (no aniversário da criança e no Natal). Ela está vinculada a quatro projetos sociais no distrito de Jurema-Caucaia: Feliz Jornada e Alegria da Criança, no Rondon; Projeto Guadalajara e Tancredo Neves, no Potira.

Essa ajuda era mensal e se dava quando havia o apadrinhamento de crianças carentes por famílias estrangeiras. Os inscritos recebiam valores diferentes, dependendo da doaçáo dos "padrinhos" e da quantidade de filhos que os beneficiados possuíam. Eles variavam de 60 a 120 cruzeiros $^{12}$.Esse auxílio, além de ser de grande utilidade para os removidos, até mesmo para pagarem os terrenos, fez com que eles se sentissem integrados, não em relação à cidade, mas em relaçáo ao Conjunto Rondon. Além da garantia da casa própria, do fim do aluguel e dessa ajuda financeira, os removidos sentiam-se integrados e/ou beneficiados pelo desfavelamento porque estavam saindo de perto do Curral, local do Arraial onde existiam casas de prostituição: Onde eu morava lá no Arraial, era de frente a uma casa de prostituta, não queria meus filhos, que eles crescessem ali não. Eu gostei daqui (Conjunto Rondon), por causa disso (SILVA, 2014).

Não sabemos ao certo para onde o programa transferiu as prostitutas do Arraial, mas, através dos jornais, constata-se que elas não foram ao Conjunto Rondon.O que demonstra certa hierarquização entre os pobres e a condenação das meretrizes com base moral e religiosa. A náo ida delas para o conjunto, juntamente com as outras famílias, além de remeter a uma prática moralizadora, ainda demonstra o quanto o programa de desfavelamento era excludente. Houve exclusáo no ato de removê-los e, sobretudo, no ato de definir quem podia ou não participar da política. A citação abaixo mostra o quanto as famílias removidas ficaram agraciadas por não morar mais próximas a essas mulheres, confirmando a fala de Dona Raimunda acima e fortalecendo nossa ideia de exclusão e de reprovação das "mundanas":

\footnotetext{
Com raras exceçôes, todos os moradores da Cinza, que vive os seus últimos momentos, estâo satisfeitos com a sua remoçáo para outros pontos da cidade, principalmente os conjuntos Marechal Rondon e Alvorada, implantados pela Prefeitura Municipal, para alojar as famílias deslocadas daquele antro de vício, marginalização e prostituição. Para evitar que o extermínio de Cinza resulte apenas na transferência de local de uma zona de prostituição, a Prefeitura Municipal não incentiva a ida de mundanas, para esses conjuntos, onde são recebidas e assistidas unicamente as famílias que levam vida normal, muito embora tenham convivido durante anos, em plena central de prostíbulos (Correio do Ceará, 23/02/1973, 3).
}

12 Decreto no 73.995, de 29 de Abril de 1974. O salário mínimo era quase 377 cruzeiros. Disponível em:http:// www2.camara.leg.br/legin/fed/decret/1970-1979/decreto-73995-29-abril-1974-422662-publicacaooriginal-1pe.html. Acesso em 16 set. 2017. 
Segundo os removidos existiram ainda outros fatores no Conjunto Rondon que, de alguma forma, acabaram convencendo-os de que estavam sendo integrados à cidade ou, pelo menos, à nova realidade (local de moradia) deles. Dois desses fatores eram o apoio e a presença de Aldaci Barbosa, uma das mais importantes superintendentes da FSSF, no conjunto:

\begin{abstract}
A Dra. Aldaci visitou muito a gente aqui, ela andava era nas casas mesmo, ela disse, prometia nas reunióes que enquanto ela existisse ela ia fazer de tudo para que isso daqui virasse uma grande cidade. Ela era uma pessoa gente fina, bem legal mesmo, até deixou muita saudade, chorava gente aqui de todos os lados quando souberam que ela tinha falecido. Ela facilitou muita coisa, ela era a mãe da pobreza (DIAS, 2014).
\end{abstract}

Depois da remoção, a FSSF e a sua Superintendente continuaram a atender aos interesses (carências) dos transferidos, através de vários programas sociais, presentes no CSU. A continuidade desse trabalho assistencial, dentro de um contexto ditatorial pelo qual o país passava, era uma forma de manter o controle sobre essa população recém-removida e, claro, possibilitar a promoçáo política de vários estadistas. O próprio Prefeito Vicente Fialho visitava constantemente o conjunto para reforçar a sua imagem de político [...] preocupado com a humanização de Fortaleza e o bem-estar de sua população [...] (Correio do Ceará, 12/1973, p. 2).

Porém, não foram apenas esses motivos comentados que fizeram os removidos gostarem de ter ido ao conjunto ou se conformarem com a mudança, sentindo-se premiados pela política de desfavelamento. O Conjunto Marechal Rondon, embora reproduzisse alguns problemas existentes no Arraial, os quais serão discutidos no tópico a seguir, proporcionou aos seus moradores, também, alguns momentos de lazer: Depois construíram o Centro Comunitário, eles botaram uma televisáo lá de fora pro pessoal passar o tempo, pelo menos uma distração e a gente ia, aquele pessoal que ia chegando, já tinha uma televisãozinha lá em cima da coluna, pra gente se divertir um pedacinho (DIAS, 2014).

Se os antigos habitantes do Arraial foram integrados a algo, esse algo é o Conjunto Rondon. Primeiramente, porque eles nem estavam usufruindo completamente das melhorias advindas das transformaçóes espaciais, pelas quais passava Fortaleza, no início da década de 1970, o que lhes integraria de fato. Na verdade, todos os benefícios recebidos, quando da remoçáo, relacionam-se sempre ao conjunto e, consequentemente, as mudanças positivas obtidas também. Com a chegada ao Rondon ou somente quando da saída do Arraial, eles afirmam que puderam, enfim, ter alguma tranquilidade.

Esse sossego conseguido pelas famílias transferidas resultava da garantia da casa própria, a qual eliminava a preocupação de serem despejadas a qualquer momento de suas antigas moradias e/ou de verem-nas invadidas pelo mar: Morava pertim da praia, minha casa mesmo uma vez foi alagada pelo mar. O mar encheu e invadiu as casa tudo. Foi um sofrimento (DIAS, 2014). Outro elemento que trazia tranquilidade, era não pertencerem mais a favela, possibilitando-lhes criar seus filhos longe das prostitutas e dos marginais, como comentado anteriormente.

Entretanto, a política de desfavelamento de Fortaleza, ao contrário de seu discurso, não integrou o removido e a cidade. Afinal, a proposta nem era essa, a ordem era retirar. 
Só esta ação anulava qualquer tentativa de integração. E, quando construíram conjuntos longe do centro da cidade para receber esses excluídos, a intenção tornou-se ainda mais clara, o propósito era retirar e afastar. Segundo Maricato, apenas no começo dos anos 1980, existiram, de fato, tentativas de integrar o morador pobre à cidade, pois, a ação não compreendia mais a de removê-los:

Se no início da década de 70 a palavra de ordem é de remoção dos favelados, no fim da década já não se fala mais nisso. O discurso oficial é de recuperação e urbanização de favelas. As invasôes organizadas são toleradas e até auxiliadas, por vezes, pelas Secretarias de Promoção Social (MARICATO, 1987, p. 57).

Em Fortaleza, a remoção de várias aglomeraçôes precárias para os conjuntos habitacionais só apagou/escondeu esses infortúnios da área mais central e litorânea de Fortaleza. Ao transferir os favelados do Arraial Moura Brasil para o Conjunto Marechal Rondon, os administradores da capital estavam apenas transferindo mais uma favela de um local valorizado e prometido ao sistema viário e ao lazer, para outros lugares bem afastados do centro. Estes, além de possuir uma infraestrutura urbana mínima, não faziam parte dos espaços mais visados pela especulação imobiliária e/ou pelo Município. Por isso, foram escolhidos para a construçáo de conjuntos habitacionais destinados às pessoas de baixa renda.

Os problemas existentes no Arraial Moura Brasil não foram erradicados, como se pretendia, ele foi apenas deslocado para o Conjunto Rondon. Analisaremos isso melhor, posteriormente. Como a prioridade do programa era a ordem urbana e não a questáo social, a remoção apenas moveu as incômodas favelas para os conjuntos habitacionais, ao invés de eliminá-las. Mas, se a proposta era retirar para acabar com os infortúnios, a tentativa foi frustrada: As favelas continuam marcando a paisagem, numa prova de que medidas paliativas não resolvem (VALLADARES, 1980, p. 46). Atualmente, ainda existem muitos casebres às margens da Av. Leste-Oeste.

A política de desfavelamento proporcionou muitas mudanças aos segregados. Entre elas, citamos a estabilidade conseguida pela casa própria, a aquisição de um espaço melhor para criar seus filhos e o recebimento de uma ajuda financeira da CCF. Mas, para nós, houve mais a integraçáo removido-conjunto que a removido-cidade. Se antes, os retirados do Arraial, por habitar no Centro da capital, vivenciavam, mesmo que de forma limitada, a cidade e algumas práticas sociais já definidas, com a remoção, eles passaram a experimentar e a criar uma nova sociabilidade, a do conjunto habitacional:

Os moradores do Arraial Moura Brasil, que, em decorrência da modernização, se viram obrigados a deixar seu local de moradia, seu ambiente de trabalho, ignorando as relaçóes sociais cotidianas estabelecidas, rompendo com os laços de família e vizinhança, e tiveram que se adaptar a novos costumes, outras rotinas e a encontrar novos modos de vivência e convivência com novos sujeitos e novo espaço geográfico, estabelecendo, assim, novas práticas socioespaciais (PINHEIRO, 2007, p. 80).

Entretanto, pelas entrevistas, percebemos também que os primeiros anos de existência do conjunto (1973-1974) foram marcados pela permanência de vários problemas sociais e urbanos encontrados no Arraial e o surgimento de outros. Como comenta o geógrafo Carlos Pinheiro: [...] a segregação aqui não ficou apenas no plano espacial, pois foi muito 
mais além, uma vez que os moradores transferidos se encontravam sem transporte, sem energia e sem outros serviços básicos e ainda com a incumbência de construir suas próprias casas [...] (PINHEIRO, 2007, p. 76). Essas e outras dificuldades serão discutidas a partir de agora.

\title{
CONJUNTO MARECHAL RONDON: A PERMANÊNCIA DOS PROBLEMAS
}

\begin{abstract}
A Prefeitura Municipal de Fortaleza, além da indenização do barraco ao preço real e justo, oferece um terreno de 10 × 20 m nos conjuntos Marechal Rondon e Alvorada onde todos podem construir sua casa própria, desfrutando de uma infraestrutura desconhecida na favela, além de terem posto médico funcionando diariamente, com médico e enfermeiro e distribuição gratuita de medicamentos, grupo escolar municipal, chafariz com agua farta, energia elétrica na porta, transporte coletivo e toda assistência da Prefeitura Municipal. Essa transformação na vida de muitos favelados é uma conquista que muitos nunca acreditaram conseguir um dia. E todos estáo muito satisfeitos com essa radical mudança, que acresce, principalmente, a sua moral (Correio do Ceará, 23/02/1973, 3).
\end{abstract}

Essa notícia acima, publicada em fevereiro de 1973, logo no início da construção da Av. Leste-Oeste e, consequentemente, das primeiras remoçóes, expressa o discurso oficial do programa de desfavelamento de Fortaleza e quais eram as promessas feitas aos removidos. Todos esses serviços urbanos citados estavam presentes no projeto e na planta de loteamento do Conjunto Habitacional Marechal Rondon, ${ }^{13}$ mas, segundo os entrevistados, alguns deles (energia, água, transporte, grupo escolar) só foram concretizados depois da inauguraçáo do CSU Rubens Vaz da Costa, em julho de 1974, já os outros (posto médico, saneamento, esgoto) demoraram mais para existir.

Apesar de esses equipamentos urbanos terem sido prometidos aos removidos e divulgados para a cidade, nem todos foram cumpridos. Sair do Arraial e ir ao conjunto não significou apenas mudanças positivas, pois, em muitos aspectos, nada mudou. Por isto, julgamos que os primeiros anos de ocupação do Conjunto Rondon, embora trouxessem certa promoção aos moradores, foram marcados, sobretudo, pela permanência de problemas sociais e urbanos antes presentes no Arraial Moura Brasil.

O principal objetivo dessas políticas, naquele momento, em Fortaleza, era trazer uma nova ordem urbana para a cidade. Esta, realmente, mudou, através da abertura de quatro suntuosas avenidas (Leste-Oeste, Aguanhambi, Borges de Melo e José Bastos) e da retirada de favelas e favelados de suas áreas centrais. Porém, ao compararmos a cidade e o removido para analisar quem foi mais beneficiado com a política de desfavelamento ou teve suas promessas atendidas mais rapidamente, nota-se que foi aquela quem recebeu a maior atenção dos governantes.

Assim, enquanto a cidade assumia a sua nova paisagem, os transferidos conviviam com muitas das dificuldades às quais já estavam acostumados no Arraial. Para os removidos, o

Planta urbanística do Projeto Conjunto Habitacional Marechal Rondon. PMF - FSSF - SUMOV. s/d. Projeto aprovado pelo Engenheiro Pontes Vieira Filho. Documento disponível no acervo da extinta FSSF na atual HABITAFOR (Fundação de Desenvolvimento Habitacional de Fortaleza). 
Conjunto Marechal Rondon era um novo espaço, uma nova vizinhança (relativamente) e uma nova realidade social, entretanto, reproduzia vários problemas da favela erradicada, ao mesmo tempo em que revelava alguns outros. Conforme notamos nas entrevistas, a maior semelhança entre o Rondon e o Arraial, nos primeiros anos de existência do conjunto, eram as suas estruturas físicas e sociais.

Segundo os entrevistados, a aparência física do conjunto, quando da chegada, não era tão negativa, ele tinha mais espaço que o Arraial e, por estar constituído em lotes definidos e ruas pré-estabelecidas, parecia mais organizado também. Os problemas de sua estrutura física só apareceram depois. Francisco Mathias nos conta que o conjunto só tinha mato e cobra: Menina, quando cheguei aqui, aqui não tinha nada. Só tinha muito era mato e cobra. Aparecia umas caranguejeiras (aranha) desse tamanho também. Era mato, muito mato, eu capinava hoje, quando era de manhã já tava dessa altura de novo (SOUZA, 2014).

De acordo com Dona Edith, o terreno do conjunto era muito molhado (DIAS, 2014), o que dificultava a construção das casas. A dela, por suas melhores condiçóes financeiras, era uma das poucas casas de alvenaria no conjunto naquele momento. Segundo ela, sua moradia foi construída: [...] cavando o alicerce dentro d'agua, aqui era táo brejado (alagadiço) que se cavasse um metro, já tinha água [...] (DIAS, 2014) Isto, por outro lado, foi vantajoso. Como aqui não [..] tinha água e nem luz [...] (DIAS, 2014), uma das propostas da Prefeitura, para solucionar a falta de água encanada era a construçáo de cacimbas, [...] mas quem quisesse que fizesse sua cacimba, a Prefeitura não ajudava [...] (DIAS, 2014).

Assim, antes mesmo dos transferidos conseguirem construir um cômodo nos seus lotes, eles já faziam suas cisternas. Afinal, como diz Dona Raimunda: Tinha que ter (SILVA, 2014), porque o chafariz, além de ser longe, vivia lotado, mas ao menos o terreno era favorável para a construção delas. $\mathrm{Na}$ ausência de esgoto, as fossas também fizeram parte da maioria destas casas, porém, a falta de saneamento acarretava [...] a proliferação de doenças como: verminose, úlceras na pele, gripes, tuberculose, difteria e doenças de origem nervosa (MOTA, 1972, p. 21).Na casa dos três entrevistados, as cacimbas ainda existem, mas, no contexto atual, elas servem muito mais como uma forma de prevenção quando há a falta de distribuição de água no conjunto:

Tinha que ter (cacimba). Depois disso que apareceu a água da Cagece. Ai, o pessoal disse: Mulher, por que tu não entope essa cacimba? Eu digo: - Mulher, eu tô ficando é veia, num é doida não, e agora, quando falta água, tem muita gente, o pessoal vem buscar água é aqui. Eu não mandei entupir não, de jeito nenhum (SILVA, 2014).

Outro aspecto visual e, ao mesmo tempo, econômico que marcava a paisagem do Arraial e, igualmente, caracterizou o cenário urbano do conjunto era a qualidade das casas: "O material de construção das casas existentes nas favelas é, em geral, de natureza inferior; a maioria dos núcleos é constituida de casebres de taipa, cobertos de palhas e, às vezes, telha" (CEARÁ, 1967, p. 54). No Marechal Rondon, isto se repetiu, e, às vezes, até de maneira pior. Por exemplo, a moradia de Dona Raimunda lá no Arraial era de taipa, mas, no conjunto, a sua primeira casa, aliás, seu primeiro cômodo foi construído com pedaços de pano. Outros vizinhos, segundo os entrevistados, tinham casas de palha, de lona, de madeira e afins, eram poucas as de tijolo. 
Os casebres continuaram a existir, demonstrando que a política não mudou/eliminou as condiçóes inferiores das habitaçóes. Ao contrário, ela ocasionou a continuidade e/ou a piora de moradias de baixa qualidade no conjunto. Pois, quando o público-alvo do programa ia para o Rondon, o qual, no momento, era composto por lotes e náo casas, ele era colocado no alojamento improvisado pela FSSF. Lá no alojamento, no lugar em que atualmente está a Escola Santa Teresinha, eles foram constantemente pressionados pelos assistentes da Fundação para se apressar a edificar suas casas e a sair do alojamento:

\footnotetext{
Não, não, nós se virava. Lá era assim um beco assim, cheio de quarto, no nosso quarto tinha assim, deixa eu ver, umas cinco pessoas, cinco famílias quer dizer, né? Lá, no alojamento, a assistente vivia perguntando, quando vocês vão sair? E fazer a casa? Se mudar? Isso me irritava, eu ficava brava, com raiva daquela mulher, mandando a gente sair. Eu fiquei seis meses. Um dia ela veio me perguntar de novo, quando eu ia sair. Ai quando foi de noite, eu, ai eu fiz um quarto de pano (SILVA, 2014).
}

A Dona Raimunda ficou seis meses no alojamento, talvez, por isso, ela era muito cobrada a construir sua casa depressa e a sair do aposento. Mas, por que a FSSF exigia isso dos removidos? Eles não percebiam ou esqueceram que essas pessoas tinham baixo poder aquisitivo para conseguir comprar um terreno e, ao mesmo tempo, poder custear a construção digna de uma moradia? A Fundação não considerou que eles tinham várias despesas com alimentação, com o pagamento do terreno e agora até com o transporte, por estarem morando longe de seus locais de trabalho? Podemos supor também que a tal exigência estava relacionada ao fato da Fundação querer findar a prestação de assistência no conjunto.

As dificuldades socioeconômicas e de habitação eram semelhantes. Ainda que agora eles tivessem mais auxílio, inclusive financeiro (CCF), em outros aspectos tudo piorou. Um exemplo foi o aumento de gastos com o transporte, pois eles ainda trabalhavam próximos ao seu antigo local de moradia: $O$ bom do arraial é que eu morava perto do meu trabalho, eu ia a pé pra Floriano Peixoto, pra sede da Fundação, ia pra praia, mas aqui (Rondon) também foi bom (SILVA, 2014). Foi bom, porque segundo ela, pelo menos eles tinham como se locomover para o Centro da cidade. Porém, mudar-se para o conjunto implicou no aumento de custos com o deslocamento, algo que antes praticamente inexistia no orçamento deles.

Algumas das propostas do Programa de desfavelamento de Fortaleza eram construir conjuntos próximos às áreas de serviços urbanos, como o mercado de trabalho, e, sobretudo, com a possibilidade de ter acesso fácil aos transportes (no caso, trem e ônibus). Porém, o Conjunto Marechal Rondon atendia apenas a esta última. Esses dois meios de transportes, na década 1970, funcionavam com uma regularidade bem menor, porque ambos tinham a linha ou frota reduzida e só "rodavam" duas vezes por dia (de manhá para levá-los ao trabalho e ao entardecer para trazê-los): $O$ transporte era bom, tinha o trem, $o$ ônibus, só duas vezes por dia, quem perdesse, vinha a pé, lá do Tabapuá (SILVA, 2014).

Outro aspecto do Conjunto Rondon, quanto a sua estrutura, era a falta de iluminação, saneamento e esgoto. O primeiro problema foi resolvido depois de[...] muito chá de cadeira na Prefeitura de Fortaleza [...] (DIAS, 2014). A solução do segundo veio a se 
concretizar apenas nos anos 2000, juntamente com a do terceiro. Entretanto, dos três, o último foi o mais lembrado como um incômodo pelos entrevistados. Através da entrevista de Dona Raimunda, percebemos que os esgotos abertos no Conjunto Rondon incomodavam bastante:

Quando eu vim, quando eu vim, eu primeiro mandei limpar o quintal, criatura, a "ruma" de estrume misturado com "merda" aí da vizinha, dessa altura assim, uma coisa horrível. Ai eles ficaram foi tempo, botando água no rego que passava aqui por dentro do meu quintal, né? Ai eu reclamei, porque assim também não pode, né? Eu paguei pra limpar e ficar numa situação dessa? (SILVA, 2014).

Essa característica do conjunto antes existia no Arraial. Os jornais, ao falar sobre o desfavelamento da capital, comentam que a transferência dos moradores para o Rondon proporcionar-lhes-ia melhores condiçóes de higiene. Mas, isto náo ocorreu. Pois, o conjunto, além de não ter uma rede de esgoto, à época, não permitindo tal melhoria, era constituído de poucas casas com banheiros e/ou aparelhos sanitários. Ou seja, o cenário do Arraial repetiu-se no Rondon:

Há que considerar os benefícios de ordem social para inúmeras pessoas que moram no Arraial Moura Brasil e na Cinza em condiçôes precárias, jogando seus excrementos na rampa do lixo, em meio à fedentina que poluía cada vez mais o ambiente, por não ter as suas habitações aparelhos sanitários próprios para suas necessidades (O Povo, 05/10/1974, 28).

É importante ressaltar como essas questóes sanitárias tão combatidas no centro das cidades, inclusive de Fortaleza, náo geravam preocupação para as autoridades, quando o local se tratava de conjuntos habitacionais e de periferias. As políticas habitacionais e urbanas, a nível nacional ou local, além de excluir e segregar os pobres das cidades, também acabam negando-lhes o direito de receber os mesmos cuidados dados aos ricos. Ocorria, assim, a negligência do Estado quanto ao fornecimento de melhores condiçóes de habitação, infraestrutura urbana, saúde e higiene para os removidos.

Não à toa, vários problemas espaciais e socioeconômicos do Arraial continuaram reproduzindo-se no Conjunto Rondon. Ora, a principal finalidade do prefeito de Fortaleza e de sua política de desfavelamento era combater os espaços de moradia dos pobres - as favelas - do Centro da capital. Se no Arraial Moura Brasil, além de não existir esgoto, saneamento e outros equipamentos urbanos, seus moradores eram considerados como o empecilho do desenvolvimento da cidade, por que deveríamos esperar que no conjunto a realidade seria outra?

Os dois primeiros anos do Conjunto Marechal Rondon foram bastante semelhantes a realidade do Arraial Moura Brasil devido à permanência de alguns problemas sociais e urbanos que perpassaram ambos, logo, isto confirma a nossa hipótese: as políticas habitacionais priorizavam a questáo econômica e urbana em detrimento da questão social. As políticas habitacionais e, no nosso caso, o Programa de desfavelamento, no início da década de 70, praticamente só afastaram o incômodo (favela) das áreas centrais das cidades sem resolvê-lo, de fato. Assim, consideramos que o único fator positivo disso foi a obtenção, em parte, da casa própria pelos excluídos. 
Quando afirmamos que os programas habitacionais não resolveram o problema da favela, estamos nos referindo, principalmente, à perspectiva social de seus moradores. Estes moravam nas favelas por serem excluídos socioeconomicamente da cidade, quase inexistindo alguma possibilidade de sair destes locais. Afinal, [...] a favela representa ainda, em termos habitacionais, a possibilidade mais viável e econômica para as camadas de baixa renda [...] (VALLADARES, 1980, 81). Quando as políticas habitacionais passaram a construir conjuntos habitacionais para estas populaçóes, eles, na verdade, excluíram-nas ainda mais. Daí, temos o porquê de as deficiências antigas das favelas persistirem nos conjuntos.

Apesar disso, através das entrevistas, nós identificamos que os problemas do Conjunto Rondon, quer tenham sido resolvidos logo ou náo, foram encarados muito pacientemente pelos removidos, porque já faziam parte do cotidiano deles. Porém, um acontecimento, foi muito malvisto e reclamado por eles: o Marechal Rondon tornar-se um bairro de Caucaia. Isto, segundo os três entrevistados, foi o pior dilema do conjunto: O ruim é que quando eu vim pra cá, eu não vim pra Caucaia, eu vim pro Antônio Bezerra, ele (Rondon) era o último bairro do Antônio Bezerra. Depois, com o governo do Virgílio Távora com o Danilo Correia (prefeito de Caucaia), depois que eu cheguei aqui, virou Caucaia (DIAS, 2014).

Segundo os entrevistados, o local em que foi posto o Conjunto Marechal Rondon fazia parte de Fortaleza e em meados dos anos 80 passou a ser governado pelo município de Caucaia. A desvantagem dessa mudança de esfera municipal, conforme Dona Edith, foi, além da perda de alguns benefícios dados apenas aos moradores da capital e das facilidades de acesso aos seus equipamentos urbanos, muitas vezes deficiente em outras localidades como Caucaia e outras cidades da Região Metropolitana de Fortaleza, o que considerava um "decréscimo" de status ao deixar de ser uma moradora da capital. Supomos que isso também demonstra a necessidade de continuar pertencendo a Fortaleza e uma noção de hierarquização simbólica do espaço urbano pelos próprios moradores.

Mesmo diante de todas as dificuldades presentes no Conjunto Marechal Rondon, Raimunda e Edith afirmam náo terem feito escolha melhor na vida do que mudar-se para lá: O tempo passou e hoje a gente tá vendo esse grande conjunto que eu vi se levantar tudo do nada. Vim ao conjunto foi a maior benção que eu já recebi (SILVA, 2014). Entretanto, para Francisco, sair do Arraial nunca foi seu desejo. Segundo ele, de todas as suas perdas, quando veio transferido para o Rondon, as maiores foram a perda de sociabilidade entre ele e sua família e, sobretudo, a privação de não poder mais usufruir das opçóes de lazer do centro da cidade:

Quando a gente veio pra cá, tudo ficou longe, ficou mais difícil. Lá no Arraial, quando eu tava sem trabalhar, eu ia ali na praia pescar e rapidim eu pegava peixe e ou ia vender ou ia comer. Ficou difícil de ver meu irmão, porque ele continuou morando no centro e aí ficou difícil eu ir pra lá. Eu gostava do Arraial porque era perto de tudo na cidade, eu ia andar no centro, eu ia comprar alguma coisa, muito ligeiro. E quando náo tinha o que fazer, eu ia jogar bola com meus amigos, dar um mergulho no mar, passear na Praça do Ferreira [...] (SOUZA, 2014).

Assim, finalizamos este artigo ressaltando que a ida ao Conjunto Marechal Rondon foi vista como vantajosa, tanto pela garantia da casa própria quanto por hoje os removidos 
desfrutarem de muitas melhorias espaciais ocorridas ao longo desses 44 anos de remoçáo. Entre as divergências e convergências das memórias e visóes dos entrevistados acerca do (re)ordenamento urbano de Fortaleza, da construçáo da Avenida Leste-Oeste e da chegada ao Conjunto Rondon, destacamos que para todos o Arraial sempre vai deixar saudades, mas apenas no Rondon eles, de fato, viram a si próprios como cidadáos, porque puderam, enfim, realizar o "sonho" da casa própria. Toda a luta ou as dificuldades encontradas quando da saída do Arraial, como transporte, infraestrutura e distância do local de trabalho, atualmente são lembradas enquanto um desafio vencido, uma etapa anterior as bonanças.

Entretanto, apesar dos moradores sentirem-se beneficiados com a casa própria, fruto de muito trabalho e dedicação, pois a prefeitura não os ajudava com a construçáo, o Programa Integrado de desfavelamento náo pode ser considerado uma política integradora e social. Além de surgir para fins urbanos e econômicos, utilizando o discurso social para convencer a população a aceitar as mudanças, o programa não se preocupou em dotar de equipamentos urbanos e de saneamento básico os conjuntos habitacionais destinados aos removidos. Em resumo, o objetivo era retirá-los, afastá-los e escondê-los, para que as áreas centrais da capital ocultassem a presença dos pobres. 


\section{REFERÊNCIAS:}

ARAGÃO, Thêmis A. Influência das políticas habitacionais na construçáo do espaço Urbano metropolitano de Fortaleza - História e perspectivas. Dissertaçáo de Mestrado em Planejamento Urbano e Regional, Universidade Federal do Rio de Janeiro, Rio de Janeiro, 2010.

AZEVEDO, Sergio. Vinte e dois anos de política de Habitação Popular (1964-86):criação, trajetória e extinção do BNH. Revista Administração pública. Rio de Janeiro, dezembro, 1988.

BONDUKI, Nabil Georges. Origens da habitaçáo social. Arquitetura moderna, Lei do Inquilinato e difusão da casa própria. São Paulo: Estação Liberdade: FAPESP, 1998.

BOSI, Alfredo. Dialética da colonização. São Paulo: Companhia das Letras, 1992.

CEARÁ, Governo do Estado. As migraçôes para Fortaleza. Secretaria de Administração. Fortaleza-Ceará, 1967.

FORTALEZA, Prefeitura Municipal de. Programa integrado de desfavelamento de Fortaleza: estudo preliminar. Secretaria Municipal de Planejamento. Coordenadoria de Desenvolvimento Urbano de Fortaleza. Fundaçáo do Serviço Social de Fortaleza. Fortaleza, 1973.

MARICATO, Ermínia. Política Habitacional no Regime Militar: do milagre brasileiro à crise econômica. Rio de Janeiro: Editora Vozes, 1987.

MOTA, Antônia Erika S. Uma experiência em desfavelamento: Conjunto Marechal Rondon. Trabalho de Conclusão de Curso (Graduação em Serviço Social), Universidade Federal do Ceará, Fortaleza, 1972.

NEVES, Frederico de Castro. A multidão e a história: saques e outras ações de massas no Ceará. Rio de Janeiro: Relume Dumará; Fortaleza, CE: Secretaria de Cultura e Desporto, 2000.

PERUZZO, Dilvo. Habitação: controle e espoliação. São Paulo: Cortez, 1984.

PESAVENTO, Sandra Jatahy. História e História cultural. Belo Horizonte: Autêntica Editora, 2014.

PINHEIRO, Carlos H. Lopes. Desenvolvimento urbano e seus reflexos socioespaciais: Estudo da relação entre a populaçáo e uma política de produção do espaço urbano no Arraial Moura Brasil - Fortaleza - Ceará. Dissertação de Mestrado em Políticas Públicas e Sociedade. Universidade Estadual do Ceará, Fortaleza, 2007.

RIOS, Kênia Sousa. Campos de Concentração do Ceará: isolamento e poder na seca de 1932. Fortaleza: Museu do Ceará/Secretaria da Cultura e Desporto do Ceará, 2001.

VALLADARES, Lícia do Prado. Passa-se uma casa. Analise do programa de remoçáo de Favelas do Rio de Janeiro. 2 ed. Rio de Janeiro: Zahar Editores, 1980.

Recebido: 29/5/2017

Aceito: 3/10/2017

Direito ou discurso? Reflexões sobre o "sonho" da casa própria no Brasil e em Fortaleza-CE (1930-1974) 